\title{
Finding the Epicenter of I-O Psychology
}

\section{Dan Sachau, Lisa Perez, and Carolyn Catenhauser Minnesota State University, Mankato}

\section{Latitude 44.1506, Longitude $\mathbf{- 9 4 . 0 0 0 2}$}

Where is the epicenter of I-O psychology in the U.S.? Where is the location around which all research, teaching and consulting revolves? Is it East Lansing, the home of Michigan State? No. Is it Bowling Green, Ohio, SIOP headquarters? No, but you are getting closer. How about Champaign, IL? Is the University of Illinois the epicenter? Warmer still, but not quite there. The center of U.S. I-O psychology is Mount Vernon, Illinois.

There is not an I-O psychologist within 30 miles of Mount Vernon, so how, you might ask, can Mt. Vernon be the center of SIOP? By our calculations, Mt. Vernon is the demographic center of I-O psychology. That is, Mt. Vernon is the average location of U.S. SIOP members. We plotted 2,884 of the U.S. SIOP members on a map by his or her zip code. We obtained the zip codes from the 2002-2003 SIOP Membership Directory. ${ }^{1}$ We then obtained the latitude and longitude for the center of each zip code. Next, we found the weighted centroid of the map. This point is the mean of the latitude and longitude pairs. Geographers also refer to this point as the population center of gravity. As the U.S. Census Bureau puts it, "The center is determined as the place where an imaginary, flat, weightless and rigid map of the United States would balance perfectly" if all SIOP members "were of identical weight and were placed on the map" (U.S. Census Bureau, 2001). For example, the centroid for the entire U.S. population is Edgar Springs, Missouri. A weighted population map of the United States would balance on the point of a very large needle situated under Edgar Springs (U.S. Census Bureau, 2002). The map of U.S. SIOP members would balance at the end of North Valley Road in Mount Vernon.

Is the centroid a sensitive measure? Well, when Tilman Sheets left Minnesota State to take a job at Louisiana Tech (We were sad to see him go.), he moved the centroid south by 502 yards. If Jose Cortina left his job at George Mason University in Virginia and moved to the University of Hawaii, he would personally drag the centroid $1 \frac{1}{2}$ miles west to Camp Ground, IL.

Is information about the centroid of any value at all? Sort of, if SIOP held the national conference near the centroid, they would minimize the average distance that SIOP members would have to travel to the conference. Where is the closest major city to the centroid? St. Louis, Missouri, is only 80 miles west of the centroid. Las Vegas is, more or less, a close second at 1,675 miles.

Are there any accolades that can be bestowed upon the central-most members of I-O psychology? Maybe. Margaret Stockdale, an associate

1 We did not include student affiliates or international members. 
professor at Southern Illinois University in Carbondale is the SIOP member closest to the center (44 miles). Southern Illinois University at Edwardsville (67 miles) is the centermost graduate program in I-O psychology. For those of you who would like to check your claim to the title of Centermost Member/Program, the geocodes for the SIOP center are latitude 38.34614768 and longitude -88.80290035 .

But wait, we have only focused on the mean. What about the oft-ignored median? Isn't there a median SIOP location? We asked ourselves the same question. We found the median latitude of members $(50 \%$ of the SIOP members live to the north of this line and $50 \%$ live to the south of this line) and the median longitude of the members ( $50 \%$ to the east and $50 \%$ to the west). We then found the intersection of the medians.

Where is the grand median of SIOP? It's Kenwood Country Club in Cincinnati, Ohio, somewhere around the tennis courts (latitude 39.18514, longitude -84.38770). And who is the most median of members? Jim Grosch at the National Institute for Occupational Safety and Health. His office is a mere 6 miles from Kenwood Country Club and he can claim the title of SIOP Median Member of the year. The title for Median University goes to Xavier. Congratulations Margaret, Jim, SIU, and Xavier!

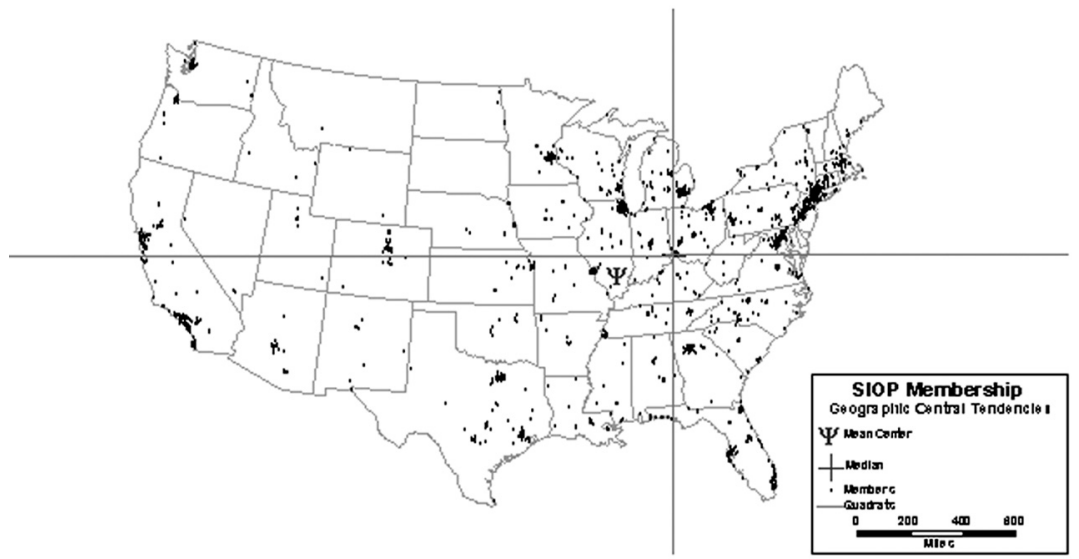

Figure 1. U.S. SIOP Members

Note: SIOP members from Alaska and Hawaii were not included in the map but were included in mean and median.

\section{References}

U.S. Census Bureau. (2002). Center of population for Census 2000. Retrieved September 30, 2003, from http://www.census.gov/geo/www/cenpop/geogctr.pdf.

U.S. Census Bureau. (2001). Centers of population computation 1950, 1960, 1970, 1980, 1990, and 2000. Retrieved September 30, 2003, from http://www.census.gov/geo/www/ centers_pop.pdf. 